\title{
Brachydactyly type A6
}

INSERM

\section{Source}

INSERM. (1999). Orphanet: an online rare disease and orphan drug data base.

Brachydactyly type A6. ORPHA:93382

Brachydactyly A6 (BDA6) is characterized by brachymesophalangy with mesomelic short limbs, and carpal and tarsal bone abnormalities. In general, the affected individuals are of slightly short stature and normal intelligence. The syndrome has been described in a kindred with seven affected members from three generations. Transmission appears to be autosomal dominant. 